\title{
Comparative profiles of Achyrocline alata (Kunth) DC. and A. satureioides (Lam.) DC., Asteraceae, applying HPLC-DAD-MS
}

\author{
Rafaela Grassi-Zampieron, ${ }^{1}$ Leonardo V. França, ${ }^{2}$ Carlos A. Carollo, ${ }^{2}$ Maria do Carmo Vieira, ${ }^{3}$ \\ Alberto Oliveros-Bastidas, ${ }^{4}$ João M. de Siqueira ${ }^{*, 5}$
}

\author{
${ }^{1}$ Curso de Pós-graduação Interinstitucional em Ciências da Saúde, UFMS/UFG/UNB, Brazil, Caixa Postal 549, \\ 79070-900 Campo Grande-MS, Brazil, \\ ${ }^{2}$ Departamento de Farmácia-Bioquímica, Centro de Ciências Biológicas e da Saúde, Universidade Federal de Mato \\ Grosso do Sul, Caixa Postal 549, 79070-900 Campo Grande-MS, Brazil, \\ ${ }^{3}$ Faculdade de Ciências Agrárias, Universidade Federal da Grande Dourados, Caixa Postal, 533, 79804-970 \\ Dourados-MS, Brazil, \\ ${ }^{4}$ Universidad de los Andes, Facultad de Ciencias, Depto de Química, Grupo de Quimica Ecologica, Nucleo \\ Universitario Pedro Rincón Gutiérrez, 5101-A, Mérida, Venezuela, \\ ${ }^{5}$ Laboratório de Farmacognosia/Produtos Naturais, Campus Centro-Oeste Dona Lindu, Universidade Federal de São \\ João Del Rei, Rua Sebastião Coelho, 400, 35501-296 Divinópolis-MG, Brazil.
}

\begin{abstract}
RESUMO: "Perfil comparativo entre Achyrocline alata (Kunth) DC. e A. satureioides (Lam.) DC., Asteraceae, utilizando HPLC-DAD-MS". Análises comparativas entre os extratos hidrometanólico de Achyrocline alata (Kunth) DC. e A. satureioides (Lam.) DC., Asteraceae,foram desenvolvidas utilizando HPLC-DAD-MS. Ambas as plantas são utilizadas indistintamente para as mesmas indicações na medicina popular de Mato Grosso do Sul, Brasil, enquanto a A. alata (“jatei-ka-há) é predominante neste estado, a A. satureioides ("marcela") é predominante nos demais estados da Federação. Amostras das duas espécies coletadas em épocas diferentes, 1996 e 2002, apresentaram o mesmo perfil cromatográfico. O presente resultado pode justificar que $A$. alata possa ser utilizada como sucedânea de $A$. satureioides, pois apresentam similar composição de metabólitos secundários polares.
\end{abstract}

Unitermos: Achyrocline, chalcona, cafeoil, perfil cromatográfico, HPLC-DAD-MS.

\begin{abstract}
A comparative analysis between the hydromethanolic extracts of Achyrocline alata (Kunth) DC. and A. satureioides (Lam.) DC., Asteraceae, was performed by the use of HPLC-DADMS. Both plants were used without distinction and under the same indications in folk medicine in Mato Grosso do Sul, Brasil. While Achyrocline alata ("jatei-ka-ha") is used in folk medicine of the Brazilian state of Mato Grosso do Sul, A. satureioides is predominantly used in other states. Samples of both plants collected in different periods, 1996 and 2002, showed a very similar chemical profile. The results indicate that $A$ alata could be used in phytotherapeutic preparations as substitue for $A$. satureioides, since they have similar chemical compositions of the polar extract.
\end{abstract}

Keywords: Achyrocline, chalcone, caffeoyl derivatives, chromatographic profile, HPLC-DADMS analysis.

\section{INTRODUCTION}

The Achyrocline genus belongs to the Asteraceae family and comprises from twenty to thirty species spread through tropical and subtropical regions of South and Central Americas, Africa and Madagascar (Bremer, 1994). Asteraceae has been one of the most studied plant families, several species are widely used in South America, such as: A. alata, A. tomentosa, A. flaccida and A. satureioides. Previous chemical investigations of $A$. alata and other species of Achyrocline collected in South
America (Argentina, Uruguay) were performed, showing similar profiles regarding to their phenolic constituents, flavonoids and quinic acid derivatives (Lopez et al., 2006, Broussalis et al., 1993).

In Brazil, A. satureioides (Lam.) DC. (popularly called "marcela") is predominant in folk medicine in most of Brazilian states, while A. alata (known as "jatei-kaha") is adopted in Mato Grosso do Sul state as a substitute of the former. Its yellow inflorescence is sligthly more yellow besides having a more pronounced odour when compared to A. satureioides. A survey of the medicinal 
plants more requested by clients or indicated by herb sellers operating in the central area of Campo GrandeMS, Brazil, was performed in two different times - 1992 and 2002. In both surveys, "jatei-ka-ha" was the third plant among the most requested ones and/or indicated by them, while "marcela" was fifteenth and nineteenth, respectively. Both plants have been used under the same preparation procedure, as well as with the same indications in folk medicine (Nunes et al., 2003). In others surveys, made in some cities of the state, in special those towards the Brazilian border with the Latin American country, in this case Paraguay and Bolivia, A. alata continued being cited as the most used species in popular medicine (Siqueira \& Palhano, 1994). However, no pharmacological report of $A$. alata was found in the literature, whereas previously pharmacological evaluations were reported about $A$. satureioides, which showed antispasmodic and relaxing effects; anti-inflammatory (Simões et al., 1988, Hnatyszyn et al., 2004, Fachinetto et al., 2007), analgesic and sedative activities, effects on intestinal transit and antioxidant action (Desmarchelier et al., 1998, Leal et al., 2006, Grassi-Zampieron et al., 2009).

Therefore, the present study was carried out to compare the chromatogram profiles obtained by HPLCDAD-MS of these both species cultivated in different times - 1996 and 2002. In addition, a further phytochemical workup of the ethyl acetate fraction obtained from hydrometanolic extract from A. alata was performed.

\section{MATERIAL AND METHODS}

\section{Plant material}

Inflorescences of Achyrocline alata (Kunth) DC. and A. satureioides (Lam.) DC., Asteraceae, were cultivated and collected in the Campus of the Universidade Federal da Grande Dourados (UFGD), Dourados-MS, Brazil, on April of the 1996 and in 2002, and identified by Dr. Lílian Auler Mentz. Voucher specimens of the plants were kept in the CG/MS herbarium (numbers 11486 and 11487, respectively).

\section{Climatic and horticulture conditions}

The plants were cultivated on April of 1996 and 2002 in the Horto de Plantas Medicinais (HPM), of the UFGD, in Dourados. Dourados city has medium altitude of $452 \mathrm{~m}$ and its climate is classified by the international system of Köppen as Cwa - humid subtropical climate (Mato Grosso do Sul State in 1990). The annual medium precipitation is nearly $1500 \mathrm{~mm}$ and the annual medium temperature is about $22{ }^{\circ} \mathrm{C}$. The average relative humidity of the air during this period was of $73.18 \%$ (Estação Agroclimatológica - UFMS). The soil is originally cerrado vegetation, and it is classified as typical Haplortox of loamy texture and flat topography. Chemical analyses of samples of the soil showed: $\mathrm{pH}: \mathrm{H}_{2} \mathrm{O}(1: 2.5)=5.3$ and 6.0; $\mathrm{P}\left(\mathrm{mg} / \mathrm{dm}^{3}\right)=14.0 ; \mathrm{K}\left(\mu \mathrm{mol} / \mathrm{dm}^{3}\right)=3.3 ; \mathrm{Al}^{3}+(\mu \mathrm{M} / \mathrm{dm}-3)$ $=0.0 ; \mathrm{Ca}^{2+}\left(\mu \mathrm{M} / \mathrm{dm}^{3}\right)=30.0 ; \mathrm{Mg}\left(\mu \mathrm{M} / \mathrm{dm}^{3}\right)=14.9 ; \mathrm{H}+\mathrm{Al}$ $\left(\mu \mathrm{M} / \mathrm{dm}^{3}\right)=78.6 ; \mathrm{Sb}\left(\mu \mathrm{M} / \mathrm{dm}^{3}\right)=42.9 ; \mathrm{CTC}\left(\mu \mathrm{Mdm}^{3}\right)=$ 121.5; V $(\%)=33.0$ and $\mathrm{Mo}(\mathrm{g} / \mathrm{kg})=29,6$.

Extracts obtained from $A$. alata and $A$. satureioides for chromatography evaluations by LC-MS analysis and usual work up.

\section{Extracts for liquid chromatography, instrumentation and conditions}

Extracts for HPLC-DAD-MS analysis were obtained by the following procedures: dried and powdered inflorescences of $A$. alata and A. satureioides $(100 \mathrm{mg})$ were extracted with $3 \mathrm{~mL}$ of $\mathrm{MeOH}: \mathrm{H}_{2} \mathrm{O}(7: 3)$ and $3 \mathrm{~mL}$ of methylene chloride was also additionated with the aim of removing apolar compounds from hydromethanolic extract. Then, this mixture was submitted to ultrasonic extraction for 20 minutes followed by centrifugation and concentration; $20 \mu \mathrm{L}$ of hydromethanolic was used. The HPLC-DAD-MS analysis were performed on a Shimadzu LC-20A HPLC apparatus with a diode array detector (CBM20A; Shimadzu) coupled to an UltrOTOFq (Bruker Daltonics) ESI-qTOF mass spectrometer. For the analytical HPLC method a monolithic column (Onyx ${ }^{\mathrm{TM}} 150$ x 4,6 $\mathrm{mm}$ - C-18 - Phenomenex) and a pre-column of the same material were used. The mobile phase consisted of a linear gradient elution at a flow rate of $3 \mathrm{~mL} / \mathrm{min}$ with the following mixtures: water:acetic acid $1 \%(\mathrm{v} / \mathrm{v})$ (phase A) and acetonitrile:acetic acid 1\% (phase B) as eluents. The first 8 min were eluted with B phase with gradient $5-12 \%$, following $13-22 \%$ (8-25 $\mathrm{min}$ ), $22-35 \%$ (25-29 $\mathrm{min}$ ), $35 \%$ (29-30 $\mathrm{min}), 35-100 \%$ (30-34 $\mathrm{min})$. The standards used were obtained from the following sources: chorogenic acid (Acros) (1,4.28 min); isoquercetrin (Merck) (2,11.98 min.) and quercetin (Merck) (8, $23.45 \mathrm{~min}$.). 4,2',4'-Trihydroxy6'-methoxychalcone (10, 30.77 min.), gnaphalin (11, 32.32 min.), 3-O-methyl-quercetin $(\mathbf{9}, 26.23 \mathrm{~min}$.) were isolated from $A$. alata. 3,5 Dicaffeoyl-quinic acid (4, 15.35 min.) and 4,5 dicaffeoyl-quinic acid (6, $17.78 \mathrm{~min}$.) were kindly given by Prof. Dr. Norberto Peporine Lopes. The retention time and UV spectra of these standards are shown in Table 1 and Figure 1.

\section{Extract from $A$. alata for fractionation on chromatography colunm}

The hydromethanolic extract from dried inflorescences of $A$. alata $(100 \mathrm{~g})$ was obtained using MeOH:H2O (7:3) at $40{ }^{\circ} \mathrm{C}(19.2 \mathrm{~g})$ and was concentrated under reduced pressure. A sample of hydromethanolic extract from A. alata $(6 \mathrm{~g})$ was subjected to liquid-liquid extraction, yielding hexane $(0.9 \mathrm{~g})$ and ethyl acetate $(1.5 \mathrm{~g})$ fraction. The fractionation of the ethyl acetate fraction on 
silica gel column using $\mathrm{CHCl}_{3}: \mathrm{MeOH}$ gradient, furnished 4,2',4'-trihydroxy-6'-methoxychalcone (10), besides other flavonoids already isolated previously (3-O-methylquercetin 9, quercetin $\mathbf{8}$, and gnaphalin 11). This chalcone was determined by $1 \mathrm{D}$ - and 2D-NMR spectrometry by a comparison of some models available in the literature (Morikawa et al., 2009, Puyvelde et al., 1989, Slimestad et al., 2008), and by UV and ESI-MS data. Spectral data of the other known flavonoids (UV, NMR) were also compared with those described in the literature (Agrawal et al., 1989).

4,2',4'-Trihydroxy-6'-methoxychalcone. $\mathrm{UV}_{\max }(\mathrm{MeOH})$ : 230 and $340 \mathrm{~nm} ;{ }^{1} \mathrm{H}-\mathrm{NMR}$ (400 MHz, DMSO-d ${ }_{6}$ ): $\delta 13.94$ (br s, H), 10.87 (br s, H), 10.10 (br s, H), disappeared after addition of $\mathrm{D}_{2} \mathrm{O}, 7.66(\mathrm{~d}, J=15.1 \mathrm{~Hz}, \mathrm{H}-\alpha), 7.58(\mathrm{~d}, J=$ $15.1 \mathrm{~Hz}, \mathrm{H}-\beta), 7.36(\mathrm{~d}, J=8.4 \mathrm{~Hz}, \mathrm{H}-2$ and 6$), 6.76(\mathrm{~d}$, $J=8.4 \mathrm{~Hz}, \mathrm{H}-3$ and 5), 5.88 (d, $J=2.0 \mathrm{~Hz}, \mathrm{H}-5$ '), 5.86 (d, $\left.J=2.0 \mathrm{~Hz}, \mathrm{H}-3^{\prime}\right), 3.82\left(\mathrm{~s}, \mathrm{OCH}_{3}\right.$ in $\left.\mathrm{C}-6{ }^{\prime}\right) ;{ }^{13} \mathrm{C}-\mathrm{NMR}$ (100 MHz, CDCl ${ }_{3} / \mathrm{DMSO}_{6}$ ): 104.6 (C-1'), 167.0 (C-2'), 90.8 (C-3'), 164.3 (C-4'), 95.8 (C-5'), 162.3 (C-6'), 55.1 $\left(\mathrm{OCH}_{3}\right.$ in $\left.\mathrm{C}-6^{\prime}\right), 191.3\left(\mathrm{C}=\mathrm{O}, \mathrm{C}-\beta^{\prime}\right), 123.4(\mathrm{C}-\alpha), 141.9$ (C- $\beta$ ), 125.9 (C-1), 129.5 (C-2 and C-6), 115.4 (C3 and C-5), 159.2 (C-6). Main HMBC correlations observed: $\delta \mathrm{H} / \delta \mathrm{C} 3.82\left(\mathrm{OCH}_{3}\right) / 162.3$ (C-6'), 5.88(H-5')/90.8(C-3'), 5.86(H-3')/95.8(C-5'), 7.66(H- $\alpha) / 191.3\left(\mathrm{C}-\beta^{\prime}\right), \quad 7.58(\mathrm{H}-$ $\beta) / 191.3\left(C_{-} \beta^{\prime}\right)$; by ESI-MS in positive mode $\mathrm{m} / \mathrm{z} 287$ $[\mathrm{M}+\mathrm{H}]^{+} ; m / z 167\left[\mathrm{C}_{8} \mathrm{H}_{7} \mathrm{O}_{4}\right]^{+}$and in negative mode $\mathrm{m} / z 285$ were observed.

\section{RESULTS AND DISCUSSION}

The plants showed phenylpropanoids and flavonoids derivatives as the major compounds, initially characterized by their UV spectra (Table 1 and Figure 1). Among these, three dicaffeoylquinic acid derivatives were observed (peaks 3, 4 and 6); the peaks 4 and 6 were identified by comparison with authentic standards as 3,5and 4,5-dicaffeoylquinic acids, respectively. The peak 3 (retention time $14.60 \mathrm{~min}$ ) was analysed and its fragments were compared with the identification keys of these compounds proposed by Clifford et al., (2003; 2005). In these identification keys the fragment $m / z 173$ [M-2caf$\left.\mathrm{H}_{2} \mathrm{O}\right]$ - is characteristic of derivatives substituted in the position 4, besides the absence of the ions characteristic of 1,4-dicaffeoylquinic acid ( $\mathrm{m} / \mathrm{z} 299$ and m/z 203), suggests the identification of the peak 3 as being 3,4-dicaffeoylquinic acid. The peak 5 presented a UV spectrum similar to the one observed for the flavonoid quercetin; this compound showed an ion in $\mathrm{m} / \mathrm{z}$ 463.0846, compatible with the chemical formula $\mathrm{C}_{21} \mathrm{H}_{19} \mathrm{O}_{12}-(463.0876)$. This formula is the same presented by the flavonoid isoquercetrin (2), besides that, it was observed in the MS-MS spectrum (collision energy $15 \mathrm{eV}$ ) as main fragment the ion $\mathrm{m} / \mathrm{z}$ 301 , compatible with aglycone quercetin, this fragment suggested the loss of hexosyl residues $(\mathrm{m} / \mathrm{z} 162)$. By analysing these data is possible to characterize this compound as a flavonol quercetin derivative, probably glucosilated or galactosilated. The peak 7 showed a UV spectrum similar to the compound previously described, however shownig a molecular weight of $\mathrm{m} / \mathrm{z} 447.1259$. In the MS-MS spectra (collision energy $15 \mathrm{eV}$ ) it was observed that the main fragment is the ion $m / z 285$, compatible with the flavonol kaempferol, so with the presented data and by analogy with the compound previously described it is possible to characterize this peak as the flavonol kaempferol derivative probably glucosilated or galactosilated. The other picks were characterized by comparing standards by<smiles>[R20]OC1C[C@](O)(C(=O)O)C[C@H]([R20])[C@@H]1O[R]</smiles>

$1 \mathrm{R}=\mathrm{R}_{1}=\mathrm{H} ; \mathrm{R}_{2}=X$
$3 \mathrm{R}_{2}=\mathrm{R} ; \mathrm{R}=\mathrm{R}_{1}=X$
$4 \mathrm{R}_{1}=\mathrm{H} ; \mathrm{R}_{1}=\mathrm{R}_{2}=X$
$6 \mathrm{R}=\mathrm{H} ; \mathrm{R}_{1}=\mathrm{R}_{2}=X$<smiles>[X]C(C)=CC=Cc1ccc(O)c(O)c1</smiles><smiles>[R]c1ccc(-c2oc3c([R])c(O)cc(O)c3c(=O)c2[R])cc1[R]</smiles>

$2 \mathrm{R}=\mathrm{H} ; \mathrm{R}_{1}=\mathrm{R}_{2}=\mathrm{OH} ; \mathrm{R}_{3}=$ glu

$8 \mathrm{R}=\mathrm{H} ; \mathrm{R}_{1}=\mathrm{R}_{2}=\mathrm{R}_{3}=\mathrm{OH}$

$9 \mathrm{R}=\mathrm{H} ; \mathrm{R}_{1}=\mathrm{R}_{2}=\mathrm{OH} ; \mathrm{R}_{3}=\mathrm{OMe}$

$11 \mathrm{R}=\mathrm{OMe} ; \mathrm{R}_{1}=\mathrm{R}_{2}=\mathrm{H} ; \mathrm{R}_{3}=\mathrm{OMe}$<smiles>COc1cc(O)cc(O)c1C(=O)/C=C/c1ccc(O)cc1</smiles>

10 
Table 1. Identification of main compounds in the hydromethanolic extracts from A. alata and A. satureioides by retention time, UV spectra and negative ions in HPLC-DAD-ESI-MS.

\begin{tabular}{|c|c|c|c|c|c|}
\hline Peaks $N^{o}$. & $t \mathrm{R}(\min )$ & Compound & UV max $(\mathrm{nm})$ & $\begin{array}{l}\text { Negative ionization } \\
\text { MS }(\mathrm{m} / \mathrm{z})\end{array}$ & Chemical Formula \\
\hline 1 & 4.28 & Chlorogenic acid & 299,325 & $353.0877\left[^{\mathrm{M}-\mathrm{H}]^{-}}\right.$ & $\mathrm{C}_{16} \mathrm{H}_{17} \mathrm{O}_{9}^{-}$ \\
\hline 2 & 11.98 & Isoquercetrin & $254,267^{\text {sh }}, 361$ & $463.0852[\mathrm{M}-\mathrm{H}]^{-}$ & $\mathrm{C}_{21} \mathrm{H}_{19} \mathrm{O}_{12}^{-}$ \\
\hline 3 & 14.60 & 3,4-Dicaffeoyl quinic acid & 300,325 & $515.1150[\mathrm{M}-\mathrm{H}]^{-}$ & $\mathrm{C}_{25} \mathrm{H}_{23} \mathrm{O}_{12}^{-}$ \\
\hline 4 & 15.35 & 3,5-Dicaffeoyl quinic acid & 299,325 & $515.1150[\mathrm{M}-\mathrm{H}]^{-}$ & $\mathrm{C}_{25} \mathrm{H}_{23} \mathrm{O}_{12}-$ \\
\hline 5 & 16.30 & Unidentified quercetin derivative & $252,267^{\mathrm{sh}}, 364$ & $463.0846[\mathrm{M}-\mathrm{H}]^{-}$ & $\mathrm{C}_{21} \mathrm{H}_{19} \mathrm{O}_{12}^{-}$ \\
\hline 6 & 17.78 & 4,5-Dicaffeoyl quinic acid & 299,324 & $515.1146[\mathrm{M}-\mathrm{H}]^{-}$ & $\mathrm{C}_{25} \mathrm{H}_{23} \mathrm{O}_{12}^{-}$ \\
\hline 7 & 22.53 & Unidentified kaempferol derivative & 229,358 & $447.1259[\mathrm{M}-\mathrm{H}]^{-}$ & $\mathrm{C}_{21} \mathrm{H}_{19} \mathrm{O}_{11}^{-}$ \\
\hline 8 & 23.45 & Quercetin & $254,266^{\text {sh }}, 364$ & $301.0327[\mathrm{M}-\mathrm{H}]^{-}$ & $\mathrm{C}_{15} \mathrm{H}_{9} \mathrm{O}_{7}^{-}$ \\
\hline 9 & 26.23 & 3-O-Methyl-quercetin & $255,267^{\text {sh }}, 355$ & $315.0491[\mathrm{M}-\mathrm{H}]^{-}$ & $\mathrm{C}_{16} \mathrm{H}_{11} \mathrm{O}_{7}^{-}$ \\
\hline 10 & 30.77 & 4,2',4'-Trihydroxy-6'-methoxychalcone & 367 & $285.0756[\mathrm{M}-\mathrm{H}]^{-}$ & $\mathrm{C}_{16} \mathrm{H}_{13} \mathrm{O}_{5}^{-}$ \\
\hline 11 & 32.32 & Gnaphaliin & $265,314^{\mathrm{m}}$ & $313.0710\left[\mathrm{M}-\mathrm{H}^{--}\right.$ & $\mathrm{C}_{17} \mathrm{H}_{13} \mathrm{O}_{6}^{-}$ \\
\hline
\end{tabular}

sh - shoulder, m minor peak

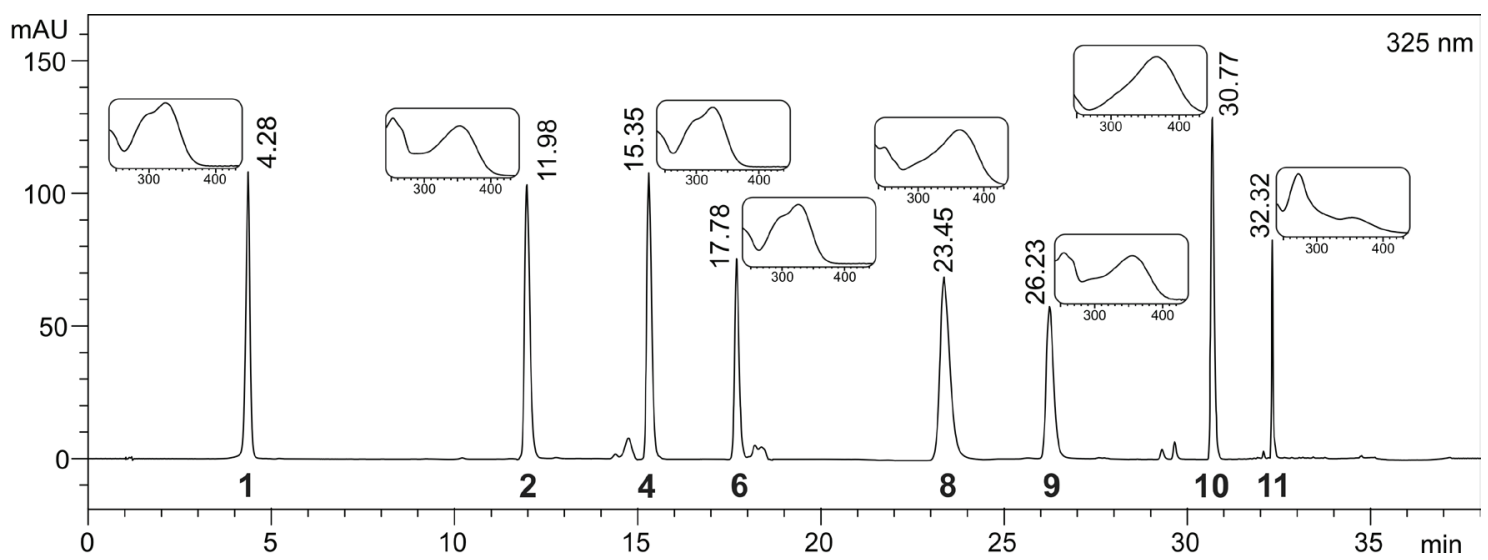

Figure 1. Chromatogram of the standards used for identification of the compounds present in the two species. In detail can be observed the UV spectra of these compounds $(250-450 \mathrm{~nm})$.

retention time, UV spectra and molecular weight in high resolution.

The HPLC analysis with diode array detection revealed similar composition of the two species (Figure 2), without a great variation for the different years when the species were collected. This similarity was also confirmed by comparison of the spectra generated by the mass analysis (data is not presented). It can only be observed a quantitative variation between the species, mainly for the chalcone 4,2',4'-trihydroxy-6'-methoxychalcone, that shows a larger accumulation in A. alata. By usual phytochemical work up, this chalcone was isolated from A. alata along with flavonoids already isolated from this species, previously, but it is being described for the first time in these species.

Determination of caffeoyl derivatives content in native Achyrocline species from Argentina and Uruguay were recently evaluated, being observed a similar chemical profile between them. According to them, the major content of caffeoyl derivatives in species of Achyrocline could justify some of their uses in folk medicine (Lopez et al., 2006). Finally, due to great chemical similarity among the secondary metabolites of the two species could be suitable justify for the indication of the A. alata to be used in phytotherapeutic preparations as a substitute for A. satureioides in the folk medicine, despite further pharmacological evaluations are necessary to confirm this point of view.

\section{ACKNOWLEDGMENTS}

The authors are grateful to FUNDECT-MS, Brazil, for the financial support and to PIBIC-CPq-PROPP-UFMS for a fellowship. Thanks are also given to FCFRP-USP-SP and Professor Norberto Peporine Lopes for making their facilities available for additional analysis (HPLC-DADMS), and the Chemistry Departament of UFMG to obtain the NMR spectral data. 


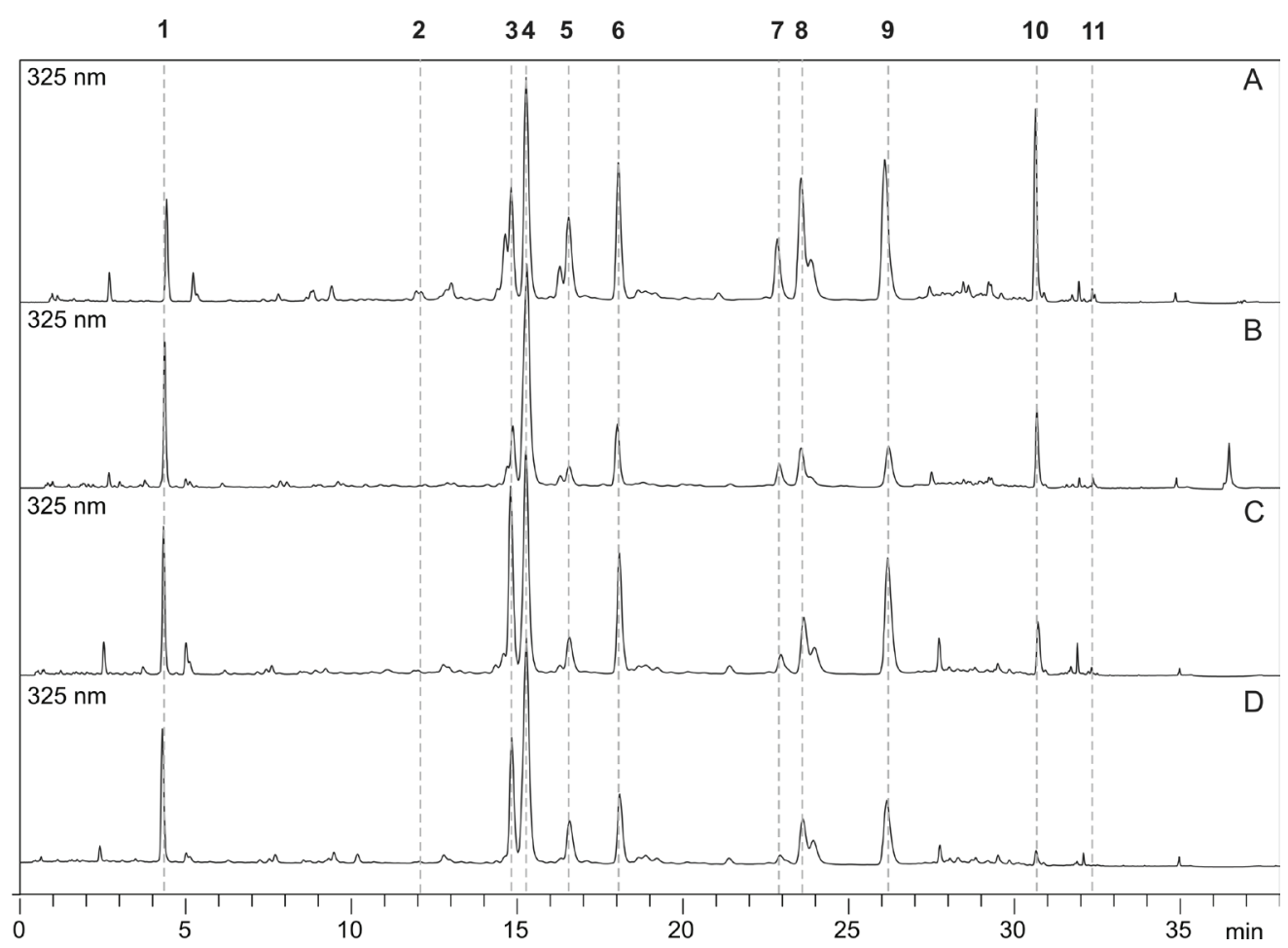

Figure 2. Chromatograms of the two species A. alata (A. collected in 1996; B. collected in 2002) and A. satureioides (C. collected in 1996; D. collected in 2002). Detection at $325 \mathrm{~nm}$. The chromatographic peak identities are reported in Table 1.

\section{REFERENCES}

Agrawal PK, Bansal MC 1989. Carbon-13 NMR of Flavonoids. New York, Elsevier.

Bremer K 1994. Asteraceae - Cladistics \& Classification. Portland: Timber Press.

Broussalis AM, Ferraro GE, Coussio JD 1993. Phenolic constituents of four Achyrocline species. Bioch Syst Ecol 21:306-306.

Clifford MN, Johnston KL, Knight S, Kuhnert N 2003. The cinnamoyl-amino acid conjugates of green robusta coffee beans. J Agric Food Chem 51: 2900-2911.

Clifford MN, Knight S, Kuhnert N 2005. Discriminating between the six isomers of dicaffeoylquinic acid by LC-MS. $J$ Agric Food Chem 53: 3821-3832.

Desmarchelier C, Coussio J, Ciccia G 1998. Antioxidant and free radical scavenging effects in extracts of the medicinal herb Achyrocline satureioides (Lam.) DC. ("marcela"). Braz J Med Biol Res 3: 1163-1170.

Fachinetto JM, Bagatini MD, Durigon J, Silva ACF, Tedesco SB 2007. Efeito anti-proliferativo das infusões de Achyrocline satureioides DC (Asteraceae) sobre o ciclo celular de Allium cepa. Rev Bras Farmacogn 17: 49-54.

Grassi-Zampieron R, Vieira MC, Siqueira JM de 2009. Atividade antioxidante e captora de radicais livres dos extratos de $A$ alata em comparação com extratos de $A$ satureioides. Rev Bras Farmacogn 19: 572-576.

Hnatyszyn O, Moscatelli V, Rondina R, Costa M, Arranz C, Balaszczuk, Coussio JD, Ferraro GE 2004. Flavonoids from Achyrocline satureioides with relaxant effects on the smooth muscle of guinea pig corpus cavernosum. Phytomedicine 11: 366-369.

Leal PF, Queiroga CL, Rodrigues MVN, Montanari I, Meireles
AA 2006. Global yields, chemical composition, and antioxidant activities of extract from Achyrocline alata and Achyrocline satureioides. Phcog Mag 2: 153-159.

Lopez P, Ferraro GE, Broussalis AM 2006. Determinación del contenido de derivados cafeilquinicos em especies sudamericanas del genero Achyrocline. Acta Farm Bonaer 25: 571-573.

Morikawa T, Wang L-B, Ninomiya K, Yokoyama E, Matsuda H, Muraoka O, Wu L-J, Yoshikawa M 2009. Medical flowers. XXVII. New flavanone and chalcone glycosides, arenariumosides I, II, III, and IV and tumor necrosis factor- $\alpha$ inhibitors from everlasting, flowers of Helichrysum arenarium. Chem Pharm Bull 57: 361-367.

Nunes GP, Silva MF da, Resende UM, Siqueira JM de 2003. Plantas medicinais comercializadas por raizeiros no Centro de Campo Grande, Mato Grosso do Sul. Rev Bras Farmacogn 13: 89-93.

Puyvelde LC, Kimpe N de, Costa J, Munyjabo V, Nyrankuliza S, Hakizamungu E, Schamp N 1989. Isolation of flavonoids and chalcone from Helichrysum odoratissimum and synthesis of helichrysetin. J Nat Prod 52: 629-633.

Simoes CMO, Schenkel EP, Bauer L, Langeloh A 1988. Pharmacological investigations on Achyrocline satureioides (Lam.) DC., compositae. J Ethnopharmacol 22: 281-293.

Siqueira JM de, Palhano PC 1994. Levantamento de plantas medicinais utilizadas no município de Amambai-MS In Resumo do XIII Simpósio de Plantas Medicinais Fortaleza.

Slimestad R, Fossem T, Verheul MJ 2008. The flavonoids of tomatoes. J Agric Food Chem 56: 2436-2441. 